\title{
BIOEDUSCIENCE
}

ISSN: 2614-1558

\section{Determination of Optimization of Nutritional Deficiencies in Plant Physiology Practicum in Hydroponic Laboratories (Axis and No-Axis System)}

\author{
Sumiati $^{*}$, M. Akmal Surur¹. \\ ${ }^{1}$ Universitas Islam Negeri Walisongo Semarang, Jl. Walisongo No. 3-5, Tambakaji, Kec. Ngaliyan, Kota Semarang, Jawa Tengah, Indonesia, \\ 50185
}

*Correspondent Email: Sumiati@walisongo.ac.id

Check for updates

\section{ARTICLE INFO}

\section{Article history}

Received: 24 Oct 2021

Accepted: 22 Nov 2021

Published: 31 Dec 2021

\section{Keyword:}

Deficiency nutrient;

Kale plant;
Work procedure;

\section{A B S T R A C T}

Background: Hydroponics is a method of agriculture that utilizes water as a planting medium. The purpose of the study was to find out reasonable working procedures and nutrient solution formulas capable of showing symptoms of morphological nutritional deficiencies in plants. Methods: The plants used are the seeds of kale plants that are sown within 1 - 2 weeks (until roots, stems, and leaves grow). The design used is Random Group using three formulas with nine kinds of treatment on each formula and three repeats. Experiments were conducted on two hydroponic systems, the axis and without the axis. The parameters observed are the number of leaves, the leaves' length, the leaves' width, the plant's height, and the plant's size. Results: Observational data in the analysis using SPSS 25. The effect of treatment with test parameters is seen using ANOVA analysis and BNT advanced tests. Visual observations showed the formula of nutrient solutions 1, 2 and 3 using both the axis system and without the axis showed symptoms of nutritional deficiencies in kale plants. The axis less system experiment gave more significant results on all parameters except leaf length than the axis system based on the average results of BNT advanced tests. Conclusion: Nutrient solutions 1, 2 and 3 have a real effect on all test parameters.

Penentuan Optimalisasi Defisiensi Nutrisi Pada Praktikum Fisiologi Tumbuhan di Laboratorium Secara Hidroponik (Sistem Sumbu Dan Tanpa Sumbu)

\section{A B S T R A K}

\section{Kata kunci:}

Defisiensi nutrisi;

Kangkung;

Prosedur kerja;
Background: Hidroponik merupakan metode pertanian dengan memanfaatkan air sebagai media tanam. Tujuan penelitian adalah untuk mengetahui prosedur kerja yang baik dan formula larutan hara yang mampu menunjukkan gejala defisiensi nutrisi secara morfologi pada tanaman. Metode: Tanaman yang digunakan adalah benih tanaman kangkung yang disemai dalam waktu 1 - 2 minggu (sampai tumbuh akar, batang dan daun). Rancangan yang digunakan yaitu Acak Kelompok menggunakan 3 formula dengan 9 macam perlakuan pada masing-masing formula dan 3 kali ulangan. Percobaan dilakukan pada 2 sistem hidroponik yaitu sumbu dan tanpa sumbu. Parameter yang diamati adalah jumlah daun, panjang daun, lebar daun, petambahan tinggi tanaman, dan tinggi tanaman. Hasil: Data hasil pengamatan di analisis menggunakan SPSS 25. Pengaruh perlakuan dengan parameter uji dilihat menggunakan analisis ANOVA dan uji lanjut BNT. Hasil pengamatan visual menunjukan formula larutan hara 1, 2 dan 3 baik menggunakan sistem sumbu maupun tanpa sumbu menunjukkan gejala defisiensi nutrisi pada tanaman kangkung. Percobaan sistem tanpa sumbu memberikan hasil yang lebih signifikan pada semua parameter kecuali PD (panjang daun) dibandingkan sistem sumbu berdasarkan hasil rata-rata uji lanjut BNT. Kesimpulan: larutan hara 1, 2 dan 3 berpengaruh nyata terhadap seluruh parameter pengujian.

\section{Introduction}

The growth and development of plants are greatly influenced by the availability of nutrients and minerals in the soil. Improper provision of fertilizers or nutrients results in the growth and reproduction of not optimal crops and waste energy and cost (Ruhnayat, 2007). 
Plant nutrients are distinguished into macronutrients, micronutrients, and trace elements based on nutrient needs. Macronutrient elements consist of $\mathrm{N}, \mathrm{K}, \mathrm{S}, \mathrm{Ca}, \mathrm{Mg}$, and P (Jeyalakshmi and Radha, 2017). Micronutrient elements include $\mathrm{Na}, \mathrm{K}, \mathrm{B}, \mathrm{Mn}, \mathrm{Zn}, \mathrm{Cu}$, and $\mathrm{Mo}$ and trace elements, namely $\mathrm{Al}, \mathrm{Si}, \mathrm{Au}, \mathrm{Ni}$ (Mc Cauley et al., 2011).

Mineral and nutrient deficiency disorders in plants can be diagnosed through plant analysis by determining CTL (critical deficiency level), CDL value (basic levels of deficiency), and CTL values (basic levels of toxicity) in plant tissues. CDL and CTL values are not a point of value but a range of values. (Marschner, 1995).

Practicum is a debriefing activity for students to understand theory and practice (Nisa, 2017). In addition, according to Susanti (2013), practicums can 1) practice skills, 2) prove something scientifically, and 3) allow students to integrate knowledge and skills that are owned in actual practice. So that it takes a clear and systematic standard of artistry or methods so that practicum activities can provide benefits as desired.

Formulation of deficiency solution in practicum plant physiology has been carried out by Kusrinah et al., (2019) with nutritional deficiency solution formula namely KNO3 (10 ml), MgSO4 (4 ml), Ca(No3)2 (10 ml), KH2PO4 (2 ml), FeDTA (2 ml), Micronutrients (2 ml), NaNo3 (20 ml), Mgcl2 (4), Na2SO4 (2 ml), NaHPO4 (2), CaCl2 (10 ml), KCl (10 ml) on 9 treatments that are complete, $-\mathrm{P},-\mathrm{K},-\mathrm{N},-\mathrm{Mg},-\mathrm{Ca},-\mathrm{S},-$ $\mathrm{Fe}$ - Micronutrients against kale (Ipomoea aquatic). But still not able to visualize the symptoms of nutritional deficiency in each treatment.

Harijati et $a l_{\text {., }}$ (2019) formulated the following nutritional deficiency solutions Ca $(1.5 \mathrm{ml}), \mathrm{KNO} 3(1.5 \mathrm{ml})$, MgSO4 (0.6 ml), KH2PO4 (0.03 ml), FeDTA $(0.3 \mathrm{ml})$, Micronutrients (0.0.03 ml). $3 \mathrm{ml}$ ), NaNo3 (1.5 ml), Mgcl2 (0.6), Na2SO4 (0.6 ml), NaHPO4 (0.3), CaCl2 (1.5 ml), KCl (1.5) in 9 treatments i.e. complete, $-\mathrm{K},-\mathrm{P},-\mathrm{N},-\mathrm{Ca},-\mathrm{S},-\mathrm{Fe},-\mathrm{Mg}$ -Micronutrients against corn crops (Zea mays).

To get good results related to the conformity of theory and facts in the field on practicum activities of nutritional deficiency ingredients, research "Determination of Optimization of Malnutrition in Plant Physiology Practicum in Hydroponic Laboratory (Axis System and Without Axes)" needs to be done.

The research was conducted in the hope of a nutritional optimization procedure that can visualize symptoms and know the composition of nutrient solutions that can show signs of nutritional deficiencies in test plants.

\section{Metode}

\section{Scope of Research}

The plant used is the seed of a kale plant that is sown within 1 - 2 weeks (until the roots, stems and leaves grow. The test treatment uses three different formulas with nine treatments in each procedure and three repeats using an axis and no-axis hydroponic system. The parameters observed are leaf length, leaf width, number of leaves, plant height, and plant height (Jayasinghe, 2014).

The materials used in this study were poly tex brand sponges, net pots, flannel, aluminium foil, cling wrapping, filter paper, weigh paper, label paper, equates, KNO3, MgSO4, KCl, 7H2O, KH2PO4, Ca(NO3)2, NaNO3, $\mathrm{MgCl} 2$, $\mathrm{NaH} 2 \mathrm{PO} 4, \mathrm{CaCl} 2, \mathrm{H} 3 \mathrm{BO} 3, \mathrm{MnCl} 2,4 \mathrm{H} 2 \mathrm{O}, \mathrm{ZnCl}, \mathrm{CuCl} 2,2 \mathrm{H} 2 \mathrm{O}$, Na2Mo04.2H2O, Na2SO, FeSO4.7H2O, Na2EDTA, four and water (Hardoyo et al., 2017). The kale seeds used are Bangkok kale seeds LP-1 brand red arrow stamp. Equipment used in the study included: sprayer, $\mathrm{pH}$ meter, lux meter, hygrometer, analytical scales, TDS meter, plastic tub, small tray, jam bottle, reagent bottle, beaker glass, spatula, measuring pipette, pi-pump, drop pipette, measuring glass, measuring gourd (Calbo and Ferreira, 2011).

\section{Research Methods}

The method used in this study is an experimental method, with the Group Random Design model using three formulas with nine kinds of treatments in each formula and three repeats. The study was conducted in July-September 2021.

\section{Research Procedure}

This research was conducted in several stages: 1) Preparation of kale seeds. 2) Setup of planting media. 3) The seedling stage. 4) Simple hydroponic manufacture of axis systems. 5) Simple hydroponic manufacture without axes. 6) Manufacture of macronutrient solution. 7) Manufacture of micronutrient solution. 8) Manufacture of Fe-EDTA solution. 9) How to treat formulas to kale plants using the axis system. 11) Treating formulas to kale plants using axis systems and 12) Data analysis techniques.

\section{Data Collection and Data Analysis}

The data were analyzed with SPSS 25 to see the effect of treatment with test parameters using ANOVA analysis and BNT advanced tests.

\section{Results}

\section{Result of BNT/LSD test}

The results of BNT further tests showed that all the formulas given had a real effect on all parameters, namely the number of leaves, leaf length, leaf width, plant height and plant height. This is indicated by the average results of the BNT test as follows the axis system, namely The Number of Leaves (8.10), Leaf Length (5.20), Leaf Width (0.77), Plant Height Increase (9.10), and Plant Height (15.20) and axis more minor system namely Number of Leaves (8.20), Leaf Length (5.03), Leaf Width (0.83), Plant Height Increase (9.97), and Plant Height (17.07). This 
shows that the experiment of a system without axes gave more significant results on all parameters except leaf length than the axis system.

The difference in significance level between the axis system and without the axis is influenced by the axis intermediary as a treatment solution transfer medium in each given formula. The axis system uses flannel that has a pretty good absorption. While in a system without the rootaxis of the plant is submerged by the solution of the treatment given. This makes the transfer speed of the test solution different and is at the speed of metabolic processes in the axis and without axis system experiments. The results of the BNT test on formulas 1,2 and 3 trial one and trial two can be seen in table 5 . The number followed by different letters in each column showed a fundamental difference according to the BNT/LSD test at the rate of $5 \%$.

\section{Deficiency in Kale Plants}

Nutritional deficiencies in kale plants using three different formulas showed that all formulas have a deficiency impact on test plants. Experiment 2 uses a hydroponic system without axes to provide visual deficiency results and more real analysis than the 1 st experiment using the axis system.

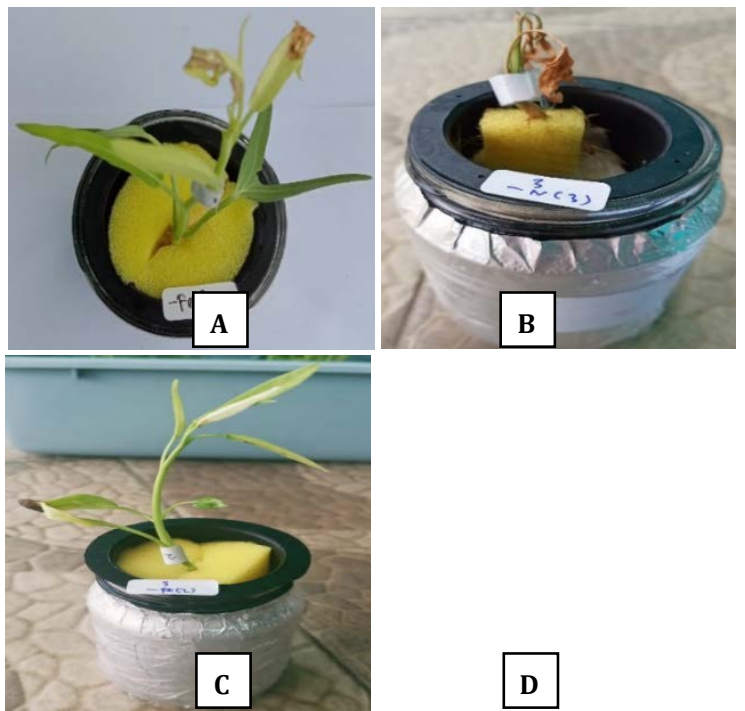

Figure 1. Symptoms of nutritional deficiency in def-fe treatment (A) Trial 1, Def-N(B) Trial 1, Def-fe(C) trial 2, Def-N(D) Trial 2

Table 1. BNT/LSD test results

\begin{tabular}{ccccccc}
\hline Formula & Experiment & $\begin{array}{c}\text { Number } \\
\text { of } \\
\text { Leaves }\end{array}$ & $\begin{array}{c}\text { Leaf } \\
\text { Length }\end{array}$ & $\begin{array}{c}\text { Leaf } \\
\text { Width }\end{array}$ & $\begin{array}{c}\text { Increase im } \\
\text { Plant Height }\end{array}$ & $\begin{array}{c}\text { Plant } \\
\text { Height }\end{array}$ \\
\hline 1 & 1 & $8,6 \mathrm{a}$ & $5,8 \mathrm{a}$ & $0,9 \mathrm{~b}$ & $11,0 \mathrm{ac}$ & $17,3 \mathrm{~d}$ \\
2 & $8,0 \mathrm{a}$ & $5,0 \mathrm{~b}$ & $0,8 \mathrm{c}$ & $9,0 \mathrm{a}$ & $14,6 \mathrm{~d}$ \\
3 & & $7,7 \mathrm{a}$ & $4,8 \mathrm{~b}$ & $0,6 \mathrm{c}$ & $7,3 \mathrm{a}$ & $13,7 \mathrm{~d}$ \\
1 & & $9,0 \mathrm{a}$ & $5,6 \mathrm{a}$ & $0,9 \mathrm{~b}$ & $12,2 \mathrm{c}$ & $19,4 \mathrm{~d}$ \\
2 & 2 & $8,2 \mathrm{a}$ & $5,1 \mathrm{a}$ & $0,9 \mathrm{~b}$ & $10,2 \mathrm{c}$ & $17,4 \mathrm{~d}$ \\
3 & & $7,4 \mathrm{a}$ & $4,4 \mathrm{~b}$ & $0,7 \mathrm{c}$ & $7,5 \mathrm{a}$ & $14,4 \mathrm{~d}$ \\
\hline
\end{tabular}

Table 2. Nutrient Solution Formula 1

\begin{tabular}{|c|c|c|c|c|c|c|c|c|c|}
\hline \multirow{3}{*}{ Solution (ml) } & \multicolumn{9}{|c|}{ Treatment } \\
\hline & \multirow[t]{2}{*}{ Complete } & \multirow{2}{*}{$\begin{array}{l}\text { Def- } \\
\mathrm{Ca}\end{array}$} & \multirow{2}{*}{$\begin{array}{c}\text { Def- } \\
\text { S }\end{array}$} & \multirow{2}{*}{$\begin{array}{l}\text { Def- } \\
\mathrm{Mg}\end{array}$} & \multirow{2}{*}{$\begin{array}{c}\text { Def- } \\
\mathrm{K}\end{array}$} & \multirow{2}{*}{$\begin{array}{c}\text { Def- } \\
\mathrm{N}\end{array}$} & \multirow{2}{*}{$\begin{array}{c}\text { Def- } \\
\text { P }\end{array}$} & \multirow{2}{*}{$\begin{array}{c}\text { Def- } \\
\mathrm{Fe}\end{array}$} & \multirow[t]{2}{*}{$\begin{array}{c}\text { Micronutr } \\
\text { ient }\end{array}$} \\
\hline & & & & & & & & & \\
\hline $\mathrm{Ca}\left(\mathrm{NO}_{3}\right)_{2}$ & 1,5 & - & 1,5 & 1,5 & 1,5 & - & 1,5 & 1,5 & 1,5 \\
\hline $\mathrm{KNO}_{3}$ & 1,5 & 1,5 & 1,5 & 1,5 & - & - & 1,5 & 1,5 & 1,5 \\
\hline $\mathrm{MgSO} 4$ & 0,6 & 0,6 & - & - & 0,6 & 0,6 & 0,6 & 0,6 & 0,6 \\
\hline $\mathrm{KH}_{2} \mathrm{PO}_{4}$ & 0,3 & 0,3 & 0,3 & 0,3 & - & 0,3 & - & 0,3 & 0,3 \\
\hline Fe EDTA & 0,3 & 0,3 & 0,3 & 0,3 & 0,3 & 0,3 & 0,3 & - & 0,3 \\
\hline Mikronutrien & 0,3 & 0,3 & 0,3 & 0,3 & 0,3 & 0,3 & 0,3 & 0,3 & - \\
\hline $\mathrm{NaNO}_{3}$ & - & 3 & - & - & 1,5 & - & - & - & - \\
\hline $\mathrm{MgCl}_{2}$ & - & - & 0,6 & - & - & - & - & - & - \\
\hline $\mathrm{Na}_{2} \mathrm{SO}_{4}$ & - & - & - & 0,6 & - & - & - & - & - \\
\hline $\mathrm{NaH}_{2} \mathrm{PO}_{4}$ & - & - & - & - & 0,3 & - & - & - & - \\
\hline $\mathrm{CaCl}_{2}$ & - & - & - & - & - & 1,5 & - & - & - \\
\hline $\mathrm{KCl}$ & - & - & - & - & - & 1,5 & 0,3 & - & - \\
\hline
\end{tabular}


Table 3. Hara Solution Formula 2

\begin{tabular}{lccccccccc}
\hline \multirow{2}{*}{ Solution (ml) } & \multicolumn{10}{c}{ Treatment } \\
\cline { 2 - 10 } & Complete & $\begin{array}{c}\text { Def- } \\
\text { Ca }\end{array}$ & $\begin{array}{c}\text { Def- } \\
\text { S }\end{array}$ & $\begin{array}{c}\text { Def- } \\
\text { Mg }\end{array}$ & $\begin{array}{c}\text { Def- } \\
\text { K }\end{array}$ & $\begin{array}{c}\text { Def- } \\
\text { N }\end{array}$ & $\begin{array}{c}\text { Def- } \\
\text { P }\end{array}$ & $\begin{array}{c}\text { Def- } \\
\text { Fe }\end{array}$ & Micronutrient \\
\hline $\mathrm{Ca}\left(\mathrm{NO}_{3}\right)_{2}$ & 3 & - & 3 & 3 & 3 & - & 3 & 3 & 3 \\
$\mathrm{KNO}_{3}$ & 3 & 3 & 3 & 3 & - & - & 3 & 3 & 3 \\
$\mathrm{MgSO}$ & 1,2 & 1,2 & - & - & 1,2 & 1,2 & 1,2 & 1,2 & 1,2 \\
$\mathrm{KH}_{2} \mathrm{PO}_{4}$ & 0,6 & 0,6 & 0,6 & 0,6 & - & 0,6 & - & 0,6 & 0,6 \\
$\mathrm{Fe} \mathrm{EDTA}_{\mathrm{Mikronu}_{4}}$ & 0,6 & 0,6 & 0,6 & 0,6 & 0,6 & 0,6 & 0,6 & - & 0,6 \\
$\mathrm{NaNO}_{3}$ & 0,6 & 0,6 & 0,6 & 0,6 & 0,6 & 0,6 & 0,6 & 0,6 & - \\
$\mathrm{MgCl}_{2}$ & - & 6 & - & - & 3 & - & - & - & - \\
$\mathrm{Na}_{2} \mathrm{SO}_{4}$ & - & - & 1,2 & - & - & - & - & - & - \\
$\mathrm{NaH}_{2} \mathrm{PO}_{4}$ & - & - & - & 1,2 & - & - & - & - & - \\
$\mathrm{CaCl}_{2}$ & - & - & - & - & 0,6 & - & - & - & - \\
$\mathrm{KCl}$ & - & - & - & - & - & 3 & - & - & - \\
\hline
\end{tabular}

Tabel 4. The formula of Nutrient Solution 3

\begin{tabular}{lccccccccc}
\hline \multirow{2}{*}{ Solution (ml) } & \multicolumn{10}{c}{ Treatment } \\
\cline { 2 - 10 } & Complete & $\begin{array}{c}\text { Def- } \\
\text { Ca }\end{array}$ & $\begin{array}{c}\text { Def- } \\
\text { S }\end{array}$ & $\begin{array}{c}\text { Def- } \\
\text { Mg }\end{array}$ & $\begin{array}{c}\text { Def- } \\
\text { K }\end{array}$ & $\begin{array}{c}\text { Def- } \\
\text { N }\end{array}$ & $\begin{array}{c}\text { Def- } \\
\text { P }\end{array}$ & $\begin{array}{c}\text { Def- } \\
\text { Fe }\end{array}$ & Micronutrient \\
\hline $\mathrm{Ca}\left(\mathrm{NO}_{3}\right)_{2}$ & 6 & - & 6 & 6 & 6 & - & 6 & 6 & 6 \\
$\mathrm{KNO}_{3}$ & 6 & 6 & 6 & 6 & - & - & 6 & 6 & 6 \\
$\mathrm{MgSO}_{4}$ & 2,4 & 2,4 & - & - & 2,4 & 2,4 & 2,4 & 2,4 & 2,4 \\
$\mathrm{KH}_{2} \mathrm{PO}_{4}$ & 1,2 & 1,2 & 1,2 & 1,2 & - & 1,2 & - & 1,2 & 1,2 \\
$\mathrm{Fe} \mathrm{EDTA}_{\mathrm{Mikronu}}$ & 1,2 & 1,2 & 1,2 & 1,2 & 1,2 & 1,2 & 1,2 & - & 1,2 \\
$\mathrm{NaNO}_{3}$ & 1,2 & 1,2 & 1,2 & 1,2 & 1,2 & 1,2 & 1,2 & 1,2 & - \\
$\mathrm{MgCl}_{2}$ & - & 12 & - & - & 6 & - & - & - & - \\
$\mathrm{Na}_{2} \mathrm{SO}_{4}$ & - & - & 2,4 & - & - & - & - & - & - \\
$\mathrm{NaH}_{2} \mathrm{PO}_{4}$ & - & - & - & 2,4 & - & - & - & - & - \\
$\mathrm{CaCl}_{2}$ & - & - & - & - & 1,2 & - & - & - & - \\
$\mathrm{KCl}$ & - & - & - & - & - & 6 & - & - & - \\
\hline
\end{tabular}

Table 5. Light Intensity, Humidity, and Environmental Temperature Data

\begin{tabular}{ccccccc}
\hline \multirow{2}{*}{ Day } & \multicolumn{2}{c}{ Morning $(06.30-07.00$ WIB $)$} & \multicolumn{3}{c}{ Afternoon $(16.30-17.00$ WIB $)$} \\
\cline { 2 - 7 } & $\begin{array}{c}\text { Temperature } \\
\left({ }^{\circ} \text { C) }\right.\end{array}$ & $\begin{array}{c}\text { Humidity } \\
(\%)\end{array}$ & $\begin{array}{c}\text { Light Intensity } \\
(\text { Lux })\end{array}$ & $\begin{array}{c}\text { Temperature } \\
\left({ }^{\circ} \mathrm{C}\right)\end{array}$ & $\begin{array}{c}\text { Moisture } \\
(\%)\end{array}$ & $\begin{array}{c}\text { Light Intensity } \\
(\text { Lux })\end{array}$ \\
\hline 1 & 28 & 66 & 2300 & 31 & 64 & 900 \\
2 & 29 & 70 & 2500 & 30 & 75 & 200 \\
3 & 28 & 77 & 7400 & 31 & 72 & 300 \\
4 & 33 & 67 & 15600 & 30 & 68 & 900 \\
5 & 29 & 60 & 6400 & 30 & 75 & 200 \\
6 & 29 & 74 & 5800 & 31 & 66 & 1500 \\
7 & 35 & 52 & 7900 & 32 & 62 & 2500 \\
8 & 28 & 72 & 7400 & 30 & 75 & 300 \\
9 & 29 & 64 & 6400 & 30 & 59 & 2200 \\
10 & 29 & 73 & 4600 & 31 & 64 & 890 \\
11 & 30 & 65 & 7900 & 30 & 70 & 320 \\
12 & 27 & 78 & 2200 & 29 & 78 & 1000 \\
13 & 29 & 74 & 7000 & 30 & 68 & 800 \\
14 & 30 & 70 & 2600 & 32 & 60 & 2200 \\
\hline
\end{tabular}

\section{Discussion}

Nutritional deficiency is when plants lack the nutrients needed for plant growth. Each plant has its uniqueness in nutritional optimization (Silva and Uchida, 2000). The first step in identifying dietary deficiencies in plants is to describe the symptoms that arise in the plant (McCauley et al., 2011). Visual observations on kale plants given formula one, formula two, and Formula three treatment using simple hydroponic methods of axis systems and simple hydroponic methods without axes show the most easily observed symptoms of leaf discolouration. This follows Wiraatmaja (2017), which explains that visual symptoms of nutritional deficiency can be seen in old leaves and young leaves (old and mature leaf blades) because leaves are the most accessible organs to observe in dietary deficiencies.

The visual symptoms of Def-Fe, Def-N, Def-Mg, aquades showed the most striking of nutritional deficiency, among other test treatments. In Def-Fe treatment, experiment one 
Showed the following symptoms: a) young leaves are yellowish-green. b) on the second week, the young leaves are yellowing and pale. c) chlorosis. These symptoms follow what the hero conveys that in plants that lack the element Fe (iron), there will be chlorosis on the sidelines of young leaves and will turn yellow in severe cases. The element Fe has an essential role in plants' respiration and photosynthetic reactions. Yellow to white discolouration is caused by a decrease in chlorophyll levels in the leaves caused by Fe deficiency (McCauley et al., 2011).

While in def-N treatment appears the following symptoms: a) dwarf and thin plants. b) Young and old leaves are brownish-yellow. c) Severe chlorosis to dry and die Wulandhari et al. (2019) Explained that plants that experience deficiency of element $\mathrm{N}$ experience discolouration in the leaves, namely brightly coloured young leaves and old leaves turn yellow. This is because Element $\mathrm{N}$ is a mobile element that can move from the old or young leaf part and provide effects to other parts of the plant when nutritional needs are not met (McCauley et al., 2011). Nitrogen is an element that must be available enough in plants as a condition of plant growth and development. The availability of nutrient elements is the structure of protein-forming components, chlorophyll, eco enzyme, purines, pyrimidines, and nucleic acids. Nitrogen is available in soil in the form of elemental nitrate (NO3-) or ammonium (NH4+) (Ahanger et al., 2016).

As for the def-mg treatment appears symptoms of nutritional deficiency as follows: a) plants look withered and limp. b) Plants grow elongated because the segment is elongated. c) the leaves of the bawar part are yellowed, brown and fall off. This follows Wulandhari et al., (2019), which explains that the symptoms of $\mathrm{mg}$ elemental deficiency are yellow leaves and eventually fall. One of the main functions of Magnesium (Mg) is its involvement in photosynthesis, as $\mathrm{Mg}$ is the element that makes up chlorophyll (Ahanger et al., 2016). Magnesium is a mobile element forming chlorophyll molecules (Silva and Uchida, 2000).

Aquades treatment is a control treatment on a series of tests. The plant is not given any nutrients in the control solution, so the plant grows dwarf, pale leaf colour. This is due to the absence of nutrients in the solution media. Plants that do not get nutrients will experience nutritional deficiencies or deficiencies.

Based on the results of observations, the three test solutions (formulas 1, 2, and 3) were able to display symptoms of nutritional deficiency in the treatment - $\mathrm{Ca}$, $\mathrm{Mg},-\mathrm{S},-\mathrm{K},-\mathrm{N},-\mathrm{P},-\mathrm{Fe}$ and - Micronutrients. But based on the BNT recap results table, experiment 2 using a hydroponic system without axes gave a higher calculation rate than experiment 1 on leaf number, leaf width, plant height, and plant height. While on the length of the leaves of experiment 1 using a higher axis hydroponic system. This is due to the absorption of nutrient deficiencies in systems without axis more than axis system, through the intermediary of the axis assistance for the transfer of nutrients from solution media. Roots in plant systems without axes will absorb directly the deficiency nutrients that exist so that it more quickly gives rise to visual symptoms of deficiency.

The comparison of formula 1 test parameter measurements showed that the parameters of leaf count, plant height, and plant height without axes gave more significant effects. While on the leaves' length and the leaves' width. While in formula two, the hydroponic system without axes gave effective results compared to the axis system in all test parameters, including the number of leaves, leaf length, leaf width, plant height accretion, and plant height.

The measurement results showed that the axis system showed significant leaf width, plant height, and plant height in formula three. While in both parameters, namely the number of leaves and the length of the leaves, the measurements using the axis system are more significant. The experiments showed that the three formulas given were able to show the results of nutritional deficiencies. Nevertheless, several points must be considered in the working procedure of practicum nutritional deficiency in kale plants.

Before implementing the practicum, the thing that must be considered is that the kale plant used must be taken entirely from the seeds/seeds, then sown first, so that kale plants have a uniform age and the same treatment. The problem/failure experienced by the previous practicum is because the sample of kale plants does not come from seeds. Still, the practice of bringing kale plants is ready to harvest and comes from different places so that the condition of kale plants has a treatment and age is not uniform. This causes symptoms of nutrient defiance in kale plants not seen in previous practices.

\section{Conclusion}

The results of different accurate tests showed that the formula of nutrient solutions 1, 2 and 3 had a natural effect on all test parameters. The parameters, namely, leaf length, leaf width, plant height, plant height, and several leaves, while based on visual symptoms that appeared, hydroponic systems without axes were better able to display symptoms than axis systems.

\section{Acknowledgement}

Thank UIN Walisongo Semarang, who financed this research in full through the BOPTN budget in 2021.

\section{Declaration Statement}

The authors reported no potential conflict of interest. 


\section{References}

Ahanger, M.A., Morad-Talab, N., Abd-Allah, E.F., Ahmad, P., Hajiboland, R., 2016. Plant growth under drought stress: Significance of mineral nutrients. Water Stress Crop Plants A Sustain. Approach 2-2, 649-668. https://doi.org/10.1002/9781119054450.ch37

Calbo, A.G., Ferreira, M.D., 2011. Evaluation of hydration indexes in kale leaves. Brazilian J. Plant Physiol. 23, 141-149. 04202011000200006 https://doi.org/10.1590/S1677-

Hardoyo, Tjahjono, A.E., Primarini, D., Hartono, Musa, 2017. Kondisi Optimum Fermentasi Asam Asetat Menggunakan Acetobacter Aceti B166. J. Sains MIPA 13, 17-20.

Harijati, N., Mastuti, R., Widoretno, W., 2019. Penuntun Praktikum Fisiologi Tumbuhan.

Jayasinghe, G.Y., 2014. Utilization of Agricultural Waste Compost as an Alternative Potting Media Component with Coir Dust for Leafy Vegetable Ipomoea Acquatica. J. Plant Nutr. 37, 1601-1611. https://doi.org/10.1080/01904167.2014.911318

Jeyalakshmi, S., Radha, R., 2017. a Review on Diagnosis of Nutrient Deficiency Symptoms in Plant Leaf Image Using Digital Image Processing. ICTACT J. Image Video Process. 7, 1515-1524. https://doi.org/10.21917/ijivp.2017.0216

Kusrinah, Sari, A.M., Adib, C.A., Nailis, I.S., 2019. Petunjuk Praktikum Fisiologi Tumbuhan (PBO-6139).

Marschner, H., 1995. Mineral Nutrition of Higher Plants. Academic Pr., San Diego.

McCauley, A., Jones, C., Jacobsen, J., 2011. Plant Nutrient Functions and Deficiency and Toxicity Symptoms. Nutr. Manag. Modul. 9, 1-16.

Nisa, U.M., 2017. Metode Praktikum untuk Meningkatkan Pemahaman dan Hasil Belajar Siswa Kelas V MI YPPI 1945 Babat pada Materi Zat Tunggal dan Campuran. J. Biol. Educ. 14, 62-68.

Ruhnayat, A., 2007. Penentuan Kebutuhan Pokok Unsur Hara N , P , K untuk Pertumbuhan Tanaman (Vanilla planifolia Andrews ). Littro XVIII, 49-59.

Silva, J., Uchida, R., 2000. Essential Nutrients for Plant Growth: Nutrient Functions and Deficiency Symptoms. Plant Nutr. Manag. Hawaii's Soils, Approaches Trop. Subtrop. Agric. 31-55.

Silva, J.A., R. Uchida, 2000. Plant Nutrient Management in Hawaii's Soils, Approaches for Tropical and Subtropical Agriculture eds, in: College of Tropical Agriculture and Human Resources, University of Hawaii at Manoa. College of Tropical Agriculture and Human Resources, University of Hawaii at Manoa.

Susanti, R., 2013. Pengaruh Penerapan Pembelajaran berbasis Masalah pada Praktikum Fotosintesis dan
Respirasi untuk Meningkatkan Kemampuan Generik Sains Mahasiswa Pendidikan Biologi FKIP Unsri. Pendidik. Biol. FKIP Unsri 1-14.

Wiraatmaja, I.W., 2017. Defisiensi dan Toksisitas Hara Mineral serta Responnya terhadap Hasil. Bahan Ajar 6.

Wulandhari, L.A., Gunawan, A.A.S., Qurania, A., Harsani, P., Triastinurmiatiningsih, Tarawan, F., Hermawan, R.F., 2019. Plant nutrient deficiency detection using deep convolutional neural network. ICIC Express Lett. 13, 971-977. https://doi.org/10.24507/icicel.13.10.971 